\title{
Kezelési költségük határozza-e meg a Magyarországon forgalmazott részvénypiaci befektetési alapok teljesítményét?
}

E tanulmány azt vizsgálja, hogy a kezelési költségekkel mennyiben magyarázható a Magyarországon forgalmazott részvénypiaci befektetési alapok teljesítménye. Az alapspecifikáció szerint, ha egy alapnak 1 százalékponttal magasabb a kezelési költsége, akkor az alap átlagosan több mint 1 százalékponttal rosszabbul teljesít a referenciahozamhoz képest (Jensen alfája). A szerző megmutatja, hogy több alap, bár hivatalosan aktív befektetési stratégiát hirdet, valójában csak az adott indexet követi. Továbbá arra is rávilágít, hogy milyen nehézségeket okoz a teljesítmény mérésében, hogy a Budapesti Értéktőzsde által létrehozott CETOP referenciaindex nem tartalmazza az osztalékokat, és kitér ennek orvoslására is. *

Journal of Economic Literature (JEL) kód: G23, G12.

A tőkepiaci hatékonyság egyik alaptétele szerint a piacok olyan hatékonyak, hogy aktív portfólióstratégiákkal sem lehet nagyobb hozamot elérni, mint ha a befektető passzív módon tőzsdeindexekbe fektette volna a pénzét. Fama [1970] megfogalmazásában, ha a piac közepesen vagy erősen hatékony, akkor minél magasabb az adott alapkezelö által felszámított kezelési költség, annál alacsonyabb hozamot kap a befektető. Hiába várnánk, hogy a magasabb költséget felszámító alapkezelők nagyobb tudású szakembereket alkalmaznak, akik jobban választják ki a részvényeket, és így magasabb hozamot érnek el a befektetők számára, ennek pont az ellenkezője igaz. Jelen cikk ezt a hipotézist teszteli magyar adatokon. Ez azért is érdekes, mert a kelet-közép-európai piacok kevésbe fejlettek, mint az amerikai, ezért elvileg elképzelhetö, hogy kevésbé hatékonyak, így aktív portfólióstratégiával mégis magasabb hozam érhetö el.

E tanulmány 24 Magyarországon forgalmazott alapot vizsgál, amelyek csak magyar, kelet-közép-európai vagy amerikai részvényekbe fektetnek be, és legalább

\footnotetext{
* Köszönöm a Budapesti Értéktőzsdének, hogy megosztotta velem a CETOP index történelmi öszszetételét. Krusper Balázsnak köszönöm az adatok összegyűjtésében és a cikk lektorálásában nyújtott segítségét. Továbbá köszönöm a két anonim bíráló segítségét.
} 
ötéves múltra tekintenek vissza. Jensen [1968] metodológiáját követve az adott piacok tőzsdeindexének hozamával korrigáljuk az alapok hozamát, így úgynevezett Jensenalfákat számolunk az egyes alapokra. Ezek az alfák értelmezhetők úgy, hogy az adott alapkezelő mennyivel tudott magasabb hozamot elérni, mint amit akkor ért volna el, ha egyszerüen az adott régió részvényindexébe fektette volna a pénzt.

A vizsgált alapok átlagos éves alfája -2,11 százalék, miközben az átlagos kezelési költségük 2,05 százalék. Ez nem meglepö, mert az alapok hozama már tartalmazza a kezelési költségeket is. Ha regressziós analízissel tovább vizsgáljuk ezen 24 alap alfája és kezelési költsége közötti összefüggést, akkor azt látjuk, hogy ha egy alap 1 százalékponttal magasabb kezelési költséget számol fel, akkor a teljesítménye (Jensen-alfája) átlagosan 1,41 százalékponttal romlik. Az alapok közel felére egyértelmủen visszautasíthatjuk azt a hipotézist, hogy a kezelési költségek növelik vagy legalábbis nem befolyásolják a befektetők által elért hozamot. Viszont a becsült együttható konzisztens a tőkepiaci hatékonysággal: az aktívabb befektetési stratégiák nem növelik a befektető által elért hozamot, a magasabb kezelési költségek viszont csökkentik.

A jelen tanulmány továbbá arra is felhívja a figyelmet, hogy a kelet-közép-európai részvényekbe fektető alapok által tipikusan referenciaként használt - a Budapesti Értéktőzsde által létrehozott - Közép-európai Blue Chip Index (CETOP) félrevezető lehet, ha azt az alapok teljesítményének értékelésére használjuk. Ennek oka, hogy a CETOP 2007. május 1-től árindexszé alakult, így nem tartalmazza az osztalékokat. E tanulmány becslése szerint a CETOP-kosár részvényei éves szinten 4,48 százalékos osztalékhozamot hoznak az árfolyamnyereségen túl. Ezért létrehozunk egy CETOPTR teljeshozam-indexet, amely a jelenlegi CETOP-részvények osztalékait is tartalmazza. Ez az elemzés ezt a CETOPTR indexet használja, és azt is megmutatja, hogy a CETOPTR teljeshozam-index nagyon jól leírható a Bécsi Tőzsde által létrehozott Central European Clearinghouses \& Exchanges elnevezésü teljeshozam-indexének (CECETR) és a Budapesti Értéktőzsde Zrt. részvényindexének (BUX) keverékével. Tehát nem feltétlenül szükséges összegyüjteni a CETOP mutató osztalékadatait, a CECETR és a BUX megfelelö keveréke is ugyanazt az eredményt adja.

A vizsgált alapok közül a csak magyar részvényekbe fektető alapok úgynevezett indexkövető alapok, amelyek a nevükben is vállalják, hogy nem próbálják meg aktívan megválasztani a befektetési portfóliójukat, és így nem is próbálnak az indexnél magasabb hozamot elérni. A jelen elemzés további eredménye, hogy rámutat: a befektetési alapok leírása nem mindig fedi a valóságot. Bár az indexkövető alapok hozamát jelentős részben az indexek hozama magyarázza, vannak magukat aktívnak hirdető alapok, ahol hasonló a helyzet. Tehát az aktívnak hirdetett alapok közül több is valójában passzív stratégiát választ (angolul: closet indexer).

A kérdés nemzetközi irodalma nagy, csak a legkorábbiakat említem itt. Carhart [1997] amerikai részvényalapokra, Blake és szerzőtársai [1993] amerikai kötvényalapokra mutatja ki, hogy az alapok teljesítményét nagyban befolyásolják a költségek. Magyar befektetési alapok adatait használva nagyon kevés tanulmány született. Bóta [2014] többfaktoros Jensen-alfákat számol magyarországi részvényalapokra, és megmutatja, hogy az alapok nem teljesítenek jobban a passzív stratégiáknál, de nem 
vizsgálja ennek okaként a kezelési költségeket. Radnai-Szatmári [2006] a magyar pénzpiaci alapokat vizsgálja, és megmutatja, hogy a költségek figyelembevételével csak kevés alap ért el többlethozamot. Ez a tanulmány tehát nem részvényalapokat vizsgál, továbbá nem vizsgálja, hogy van-e összefüggés a referenciához képesti rossz teljesítmény és a kezelési költségek között. Szatmári [2006] mind a részvény-, mind a kötvényalapok teljesítményét vizsgálja, de szintén nem tér ki a többlethozam és a kezelési költségek összehasonlítására. Erdős-Ormos [2009] pedig magyar alapokra a rövid minta miatt a napi adatok használatát javasolja. Tudtunkkal senki sem vizsgálta eddig, hogy magyar részvénypiaci befektetési alapok hosszú távon elért teljesítménye magyarázható-e a kezelési költségekkel.

\section{Adatok}

A jelen vizsgálat a befektetési alapok kiválasztásánál a következő feltételeket támasztotta. Csak a magyar befektetők részére forintban forgalmazott befektetési jegyeket vettük figyelembe. Olyan alapokat néztünk, amelyek csak magyar, kelet-közép-európai vagy amerikai részvényekbe fektetnek be, és legalább ötéves múltra tekintenek vissza. Azért koncentrált ezekre a piacokra, mert ezáltal könynyen összehasonlíthatjuk az alapok teljesítményét a releváns magyar BUX, keletközép-európai CETOP ${ }^{1}$ és amerikai Standard \& Poor's 500 (S\&P500) tőzsdeindexekkel. Amennyiben többféle sorozata van az adott alapnak, csak a kisbefektetőknek szánt $A$ jelü sorozatot vettük figyelembe. Ennek oka, hogy ha egy adott alap több sorozatát is figyelembe vettük volna, akkor az egyes alapok teljesítményét nem lehetne függetlennek tekinteni, ami megnehezítené a statisztikai elemzést.

A Befektetési Alapkezelők és Vagyonkezelők Magyarországi Szövetsége (BAMOSZ) honlapján ${ }^{2}$ és a netfolio.hu ${ }^{3}$ honlapon felsorolt alapok közül a fenti szürőknek 24 alap felelt meg. Befektetési céljuk szerint ezek közül 6 magyar, 14 kelet-középeurópai (KKE) és 4 amerikai egyesült államokbeli (USA). A továbbiakban ezeket összesen 3 alapkezelö alapjait - vizsgáljuk. Azért lehet csak viszonylag kevés alapot használni, mert sok alap befektetései földrajzilag diverzifikáltabbak, esetleg nem forintban forgalmazzák őket.

Az 1. táblázat tartalmazza a felhasznált alapok listáját és az alap nevének a továbbiakban használt rövidítését, valamint a havi megfigyelések számát, a befektetési régiót és egy indikátorváltozót, hogy az alap használ-e határidős ügyeleteket (derivatívákat) a kockázatok, fóleg a devizakockázat kezelésére. Végül a táblázat tartalmazza az egyes

\footnotetext{
${ }^{1}$ A CETOP index helyett külön használhatnánk a varsói WIG és a prágai PX-TR teljeshozamindexeket, de ez utóbbi csak 2006 márciusától áll rendelkezésre. A jelen tanulmányban nem közölt további vizsgálatok azt mutatják, hogy a CETOP index szétbontása a három fö összetevőre (BUX, PX, WIG), megengedve, hogy az alapok eltérjenek ezen piacok CETOP indexen belüli súlyától, nem befolyásolja jelentősen a becsült alfákat.

${ }^{2}$ http://www.bamosz.hu/legfrissebb-adatok.

${ }^{3}$ https://www.netfolio.hu/befektetesi_alapok_rangsora/reszvenyalapok.
} 
1. táblázat

A felhasznált befektetési alapok listája

\begin{tabular}{|c|c|c|c|c|c|c|}
\hline Rövidítés & A befektetési alap teljes neve & ISIN-kód & $\begin{array}{l}\text { Hónapok } \\
\text { száma }\end{array}$ & Régió I & Derivatíva & $\begin{array}{l}\text { Költség } \\
\text { (százalék) }\end{array}$ \\
\hline AEK & $\begin{array}{l}\text { AEGON Közép-Európai Részvény } \\
\text { Befektetési Alap }\end{array}$ & HU0000702501 & 170 & KKE & 1 & 1,95 \\
\hline AEN & $\begin{array}{l}\text { AEGON Nemzetközi Részvény } \\
\text { Befektetési Alap }\end{array}$ & HU0000702485 & 170 & KKE & 1 & 1,88 \\
\hline ALI & $\begin{array}{l}\text { Allianz Indexkövető Részvény } \\
\text { Befektetési Alap }\end{array}$ & HU0000708375 & 73 & magyar & 0 & 1,88 \\
\hline BFM & $\begin{array}{l}\text { BF Money Közép-európai } \\
\text { Részvény Alap }\end{array}$ & HU0000702717 & 170 & KKE & 1 & 2,22 \\
\hline CII & CIB Indexkövető Részvény Alap & HU0000703350 & 138 & magyar & 0 & 2,68 \\
\hline CIK & CIB Közép-európai Részvény Alap & HU0000702600 & 170 & KKE & 0 & 2,86 \\
\hline $\mathrm{COK}$ & $\begin{array}{l}\text { Concorde Közép Európai Részvény } \\
\text { Alap }\end{array}$ & HU0000706163 & 98 & KKE & 1 & 1,07 \\
\hline COR & Concorde Részvény Befektetési Alap & HU0000702022 & 170 & $\mathrm{KKE}$ & 1 & 2,15 \\
\hline ERH & Erste Hazai Indexkövető Részvény Alap & HU0000704200 & 118 & magyar & 0 & 1,04 \\
\hline ERK & $\begin{array}{l}\text { Erste Közép-európai Részvény } \\
\text { Alapok Alapja }\end{array}$ & HU0000701537 & 170 & KKE & 1 & 1,54 \\
\hline GEG & $\begin{array}{l}\text { Generali Gold Közép-kelet-európai } \\
\text { Részvény Alap }\end{array}$ & HU0000706809 & 92 & KKE & 1 & 2,23 \\
\hline GEM & $\begin{array}{l}\text { Generali Mustang Amerikai } \\
\text { Részvény Alap }\end{array}$ & HU0000705603 & 103 & USA & 0 & 3,11 \\
\hline KHA & $\begin{array}{l}\text { K\&H Amerika Alapok Nyíltvégü } \\
\text { Befektetési Alapja }\end{array}$ & HU0000701982 & 170 & USA & 1 & 2,76 \\
\hline KHK & $\begin{array}{l}\text { K\&H Közép Európai Részvény } \\
\text { Nyíltvégü Befektetési Alap }\end{array}$ & HU0000702915 & 170 & $\mathrm{KKE}$ & 0 & 1,82 \\
\hline KHN & $\begin{array}{l}\text { K\&H Navigátor Indexkövető } \\
\text { Nyíltvégü Befektetési Alap }\end{array}$ & HU0000702352 & 170 & magyar & 0 & 1,98 \\
\hline MKB & $\begin{array}{l}\text { MKB Bonus Közép-európai Részvény } \\
\text { Befektetési Alap }\end{array}$ & HU0000702964 & 170 & KKE & 0 & 1,87 \\
\hline MKE & $\begin{array}{l}\text { MKB Észak-Amerikai Részvény } \\
\text { Befektetési Alap }\end{array}$ & HU0000709506 & 63 & USA & 0 & 1,65 \\
\hline OTQ & OTP Quality Nyíltvégű Részvény Alap & HU0000702907 & 170 & KKE & 0 & 2,07 \\
\hline OTT & $\begin{array}{l}\text { OTP Tőzsdén Kereskedett BUX } \\
\text { Indexkövető Alap }\end{array}$ & HU0000704960 & 111 & magyar & 0 & 0,60 \\
\hline PIK & Pioneer Közép-európai Részvény Alap & HU0000701891 & 170 & KKE & 0 & 2,28 \\
\hline PIM & $\begin{array}{l}\text { Pioneer Magyar Indexkövető } \\
\text { Részvény Alap }\end{array}$ & HU0000701842 & 170 & magyar & 0 & 2,25 \\
\hline PIU & $\begin{array}{l}\text { Pioneer USA Devizarészvény } \\
\text { Alapok Alapja }\end{array}$ & HU0000701883 & 170 & USA & 0 & 2,37 \\
\hline QUT & Quaestor Tallér Részvény Alap & HU0000702667 & 170 & $\mathrm{KKE}$ & 1 & 2,64 \\
\hline RAR & Raiffeisen Részvény Alap & HU0000702766 & 170 & KKE & 0 & 2,38 \\
\hline
\end{tabular}


alapok díjait (költségeit) is, amelyek a legutóbbi ${ }^{4}$ kiemelt befektetői információban feltüntetett éves díjaknak felelnek meg. A befektetési alapok napi eszközértékére vonatkozó adatok a portfolio.hu oldalról származnak, ${ }^{5}$ továbbá innen valók az MNB deviza-középárfolyamai és a három hónapos állampapír referenciahozamai, amivel a kockázatmentes forintbefektetések hozamát becsülhetjük. Minden adatnál a hónap végi záróárak szerepelnek 2002. januártól 2016. március végéig. Tehát a hozamoknál 2002. februártól 2016. március végéig, alaptól függően legalább 60, de legfeljebb 170 hónappal lehet a becsléseket elvégezni.

$\mathrm{Az}$ adatelemzéshez minden adat forintosítva szerepel. Minden befektetési alap és index hozamából a többlethozam (excess return) oly módon áll elő, hogy az elöző és az adott havi záróárból kiszámolt hozamból levonjuk az adott havi forintbefektetések hozamát. A továbbiakban ezekkel a többlethozamokkal dolgozunk. A befektetési alapok esetében a számolt hozam már a befektetések kezelési költségekkel csökkentett hozama, ugyanis a rendszeres költségek csökkentik az alap eszközértékét. A vásárlási és eladási jutalékokat azonban nem tartalmazza a számolt hozam, ugyanis e jutalékoknak a befektető által elért hozamra gyakorolt hatása függ a befektetés nagyságától és időtávjától.

A Budapesti Értéktőzsde (BÉT) által számolt CETOP kelet-közép-európai index 2001 januárjától áll rendelkezésre. ${ }^{6}$ Nehézséget jelent, hogy a hivatalos CETOP teljeshozam-indexként indult, de 2007. május 1-től árindexszé alakult. Az index a későbbi időszakban nem tartalmazza az osztalékokat, így nem használható a teljesítmény referenciamutatójaként, mivel az alapok hozamában az osztalékok is szerepelnek. Így összegyüjtöttük az összes osztalékot a CETOP-ban lévő részvényekre 2007. május 1-től 2016. március 31-ig. Az elsődleges forrásunk az adott cég honlapján a befektetőknek szánt információk voltak. Másodlagos forrásként szolgáltak a Bécsi Tőzsde CECE TR teljeshozam-indexében (CECETR) használt osztalékok, ugyanis a CECE és CETOP indexek cégei között nagy az átfedés. ${ }^{7} \mathrm{Az}$ osztalék által generált többlethozam kiszámításához szükség van az adott részvény súlyára a CETOP indexen belül. A CETOP-kosár összetétele a BÉT honlapján érhető el 2008. május 16-tól, ${ }^{8}$ a korábbi időszakról pedig a BÉT bocsátott rendelkezésre nem publikus adatokat.

$\mathrm{Az}$ itt számolt teljeshozam-index (total return index) neve a továbbiakban CETOPTR. Azt feltételeztem, hogy az osztalékokat újra a CETOP-kosárba fektetjük be. A 1. ábrán látható a hivatalos CETOP index és az itt számolt CETOPTR index. Természetesen 2007. május 1-ig teljesen ugyanaz a két index, utána viszont idővel egyre jobban elválnak egymástól, ahogy egyre több osztalék kerül újból befektetésre. Míg a hivatalos CETOP 2016. március 31-én 1734,43-on zárt, addig

\footnotetext{
${ }^{4}$ Az adatgyűjtés időpontja 2016. április, a kiemelt befektetői információkat az egyes alapkezelők honlapjairól gyüjtöttük.

${ }^{5}$ http://www.portfolio.hu/history/adatletoltes.php.

${ }^{6} \mathrm{https} / / / \mathrm{www} \cdot \mathrm{bet} \cdot \mathrm{hu} / \mathrm{oldalak} /$ adatletoltes.

${ }^{7}$ https://www.wienerborse.at/en/indices/index-values/adjustments/?ID_NOTATION=22786868\&I $\mathrm{SIN}=\mathrm{AT} 0000 \mathrm{~A} 09 \mathrm{FK}$.

${ }^{8}$ Már nem érhető el a BÉT honlapján.
} 
az itt számolt CETOPTR 2563,15-on. Ez azt jelenti, hogy 2007. május 1-től a minta végéig eltelt 9 év és 11 hónap alatt a CETOPTR index a CETOP-hoz képest 47,78 százalék többlethozamot mutat, ami évesített szinten $1,4778^{12 / 107}-1=4,48$ százalék osztalékhozamot jelent. Ez jóval magasabb az amerikai piacon az S\&P500 indexnél jelenleg tapasztalt 2 százalék körüli osztalékszintnél, inkább annak 1986 elötti értékéhez hasonlít.

1. ábra

A hivatalos CETOP index és az osztalékkal igazított CETOPTR

Az index értéke (EUR)

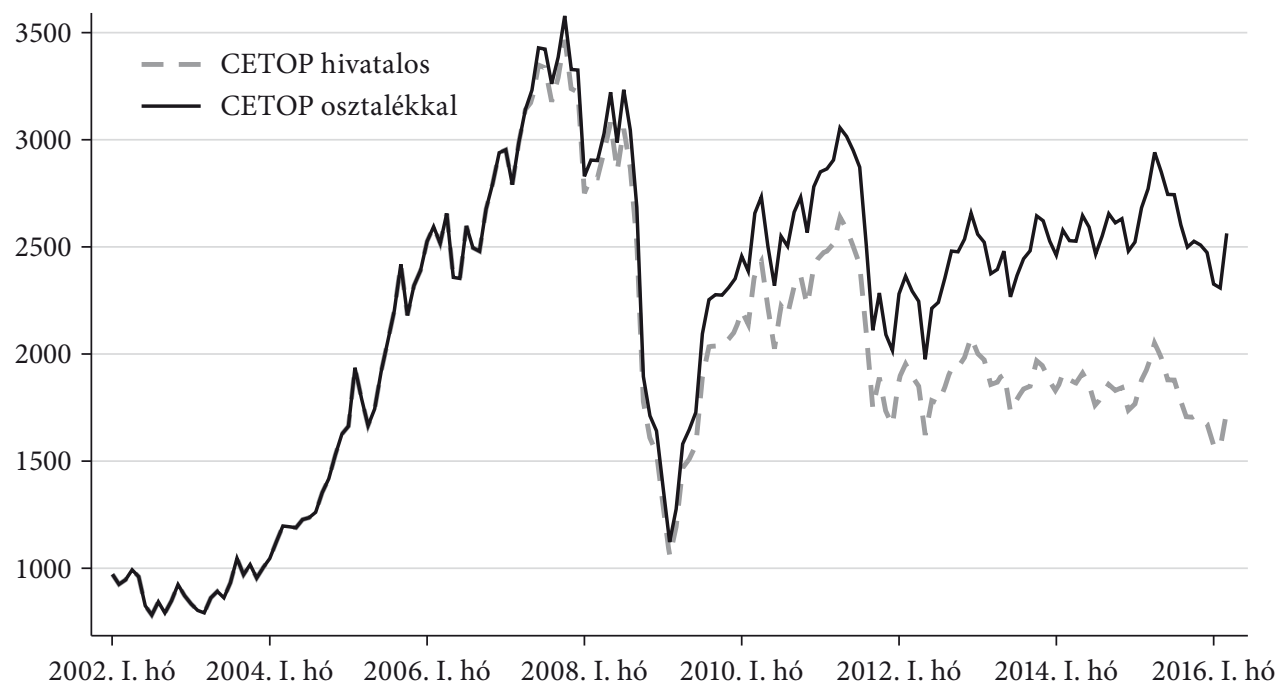

A számítások során a magyar részvénypiac teljesítményét a BUX index méri, amely egy teljeshozam-index, és elérhető a BÉT honlapján. ${ }^{9}$ Az amerikai részvények hozamát az S\&P500 index méri, amely mind teljeshozam-indexként, mind árindexként elérhető. Itt az SP500TR rövidítéssel szereplő teljeshozam-indexet használjuk a Yahoo Finance honlapról. ${ }^{10}$ A Bécsi Tözsde (Wiener Börse) által számolt CECETR kelet-közép-európai részvényindexszel is ellenőrizzük az eredmények robusztusságát, amely 2007 februárjától áll rendelkezésre. ${ }^{11}$

A határidős szerződések alapvetően befolyásolhatják az alap hozamát, így a devizakitettség hatását is figyelembe kell venni. Elöfordulhat ugyanis, hogy egy alap azért ér el magas hozamot, mert eszközeinek egy részét egy nagyon kockázatos, de magas hozamú devizában tartja. Ezt ugyanúgy az adott faktorral tudjuk kiszürni, mint a tőzsdei kockázat hatását. A következő devizákra készítünk teljeshozam-indexet: euró (EUR), lengyel zloty (PLN), cseh korona (CZK), dollár (USD). Az előbbi három a KKE-régió három legfontosabb devizája, az USD indexet az

${ }^{9}$ https://www.bet.hu/oldalak/adatletoltes.

${ }^{10} \mathrm{https} / / /$ finance.yahoo.com/quote/\%5ESP500TR/history? $\mathrm{p}=\% 5 \mathrm{ESP} 500 \mathrm{TR}$.

${ }^{11} \mathrm{https} / / / \mathrm{www}$.wienerborse.at/en/indices/index-values/historical-data/?ID_NOTATION=2278686 8\&ISIN=AT0000A09FK4. 
USA-alapokhoz használjuk. A teljeshozam-index az adott devizán elért havi százalékos (forintban számolt) árfolyamnyereség és az egyhavi kamat összege. A rövid távú kamatok az OECD honlapjáról származnak. ${ }^{12}$

\section{Eredmények}

Mivel minden alap más kockázatot vállal, a befektetési alapok többlethozamát meg kell tisztítani a vállalt kockázatok hatásától. Ez Jensen [1968] módszerével történik. Elöször az alapok többlethozamát regresszáljuk a releváns indexek többlethozamára - a KKE- és magyar alapok esetén BUX-ra és CETOPTR-re (azaz két faktorra), az USA-alapok esetében SP500TR-re. ${ }^{13} \mathrm{~A}$ határidős ügyleteket is használó alapoknál a releváns devizák többlethozamát is hozzáadjuk a magyarázó változókhoz. A regressziós egyenlet a következő:

$r_{i, t}^{e}=\alpha_{i}+\sum_{j} \beta_{i, j} \cdot r_{j, t}^{e}+\varepsilon_{i, t}$,

ahol $r_{i, t}^{e}$ az $i$-edik alap többlethozama a $t$-edik hónapban, $r_{j, t}^{e}$ a $j$-edik index többlethozama a $t$-edik hónapban. A lineáris regresszió együtthatója a j-edik indexre $\beta_{i, j}$ a hibatag $\varepsilon_{i, t}$. Jensen [1968] megmutatja, hogy ebben az esetben az $\alpha_{i}$ értelmezhető az adott befektetési alap teljesítményeként, azaz az adott alapkezelő befektetési stratégiájának hozamhoz való hozzájárulásaként. $\mathrm{Az} \alpha_{i}$ ugyanis azt méri, hogy az adott alap az indexekből rekonstruálható hasonló kockázatú portfólióhoz képest hogyan teljesít. Ez igaz több index használata esetén is.

A 2. táblázat tartalmazza az eredményeket. Minden sor egy-egy befektetési alaphoz tartozik: az első oszlop tartalmazza az adott alap rövidítését. A második oszlopban a becsült $\alpha_{i}$, az utolsó előtti oszlopban az évesített $\alpha$ szerepel, amely a kamatos kamat képletével állt elő: $(1+\alpha)^{12}-1$. Az évesített $\alpha$ könnyen összevethető az éves kezelési költséggel, amely az utolsó oszlopban található. A harmadik-kilencedik oszlopban szerepelnek a $\beta_{i, j}$-k a különböző indexekre (azaz a kockázatvállalás mértéke). A tizedik oszlopban látható az $R^{2}$.

Több érdekes megfigyelést tehetünk a becsült együtthatókkal kapcsolatban. Ha a KKEalapokat nézzük (QTQ-tól AEN-ig), és összehasonlítjuk a teljes mintán [2. táblázat A) része] és az utolsó ötéves mintán [2. táblázat $B$ ) része] kapott együtthatókat, azt látjuk, hogy míg a teljes mintán a BUX együtthatója a legtöbb esetben szignifikánsan pozitív, azaz az alapok túlsúlyozták a magyar piacot a CETOP-on belüli részesedéséhez képest, addig az utolsó öt évben a BUX együtthatója közel van a nullához a legtöbb alapnál. Ennek oka, hogy ezen alapok egy része 2007 elött inkább magyar alapként müködött, és csak a minta második felében diverzifikálták befektetéseiket a KKE-régióban.

Azon alapok devizakitettségét, amelyek a befektetőknek szánt tájékoztatás szerint határidős ügyleleteket is folytatnak, a legfontosabb valuták teljeshozam-indexével

\footnotetext{
${ }^{12}$ https://data.oecd.org/interest/short-term-interest-rates.htm.

${ }^{13} \mathrm{Ha}$ a magyar alapok esetén kihagynánk a CETOPTR indexet, hibahatáron belül ugyanazokat az alfákat kapjuk, mint a 2. táblázatban.
} 


\section{2. táblázat}

Az alapok teljesítménye és kezelési költségük

\begin{tabular}{|c|c|c|c|c|c|c|c|c|c|c|}
\hline \multirow[t]{2}{*}{ Alap } & \multirow[t]{2}{*}{ Alfa } & \multicolumn{6}{|c|}{ Béta } & \multirow[t]{2}{*}{$R^{2}$} & \multicolumn{2}{|c|}{ Éves alfa Költség } \\
\hline & & BUX & CETOPTR SP500TR & EUR & PLN & $\mathrm{CZK}$ & USD & & százalék & \\
\hline \multicolumn{11}{|c|}{ A) TELJES MINTA } \\
\hline ALI & $\begin{array}{c}-0,00154^{* * *} \\
(0,000354)\end{array}$ & $\begin{array}{l}0,975^{\star * *} \\
(0,0124)\end{array}$ & $\begin{array}{c}0,0128 \\
(0,0142)\end{array}$ & & & & & 99,7 & $-1,84$ & 1,88 \\
\hline CII & $\begin{array}{c}-0,00160^{\star * *} \\
(0,000359)\end{array}$ & $\begin{array}{l}0,985^{\star * *} \\
(0,00699)\end{array}$ & $\begin{array}{c}0,0102 \\
(0,00898)\end{array}$ & & & & & 99,6 & $-1,90$ & 2,68 \\
\hline ERH & $\begin{array}{r}0,000733 \\
(0,00233)\end{array}$ & $\begin{array}{l}0,781^{\star * *} \\
(0,0698)\end{array}$ & $\begin{array}{c}-0,150^{\star *} \\
(0,0685)\end{array}$ & & & & & 77,2 & 0,88 & 1,04 \\
\hline KHN & $\begin{array}{c}0,000326 \\
(0,00140)\end{array}$ & $\begin{array}{l}1,025^{\star * *} \\
(0,0652)\end{array}$ & $\begin{array}{l}-0,124 \\
(0,0836)\end{array}$ & & & & & 88,4 & 0,39 & 1,98 \\
\hline OTT & $\begin{array}{c}-0,000395 \\
(0,000359)\end{array}$ & $\begin{array}{l}1,003^{\star * *} \\
(0,0104)\end{array}$ & $\begin{array}{c}-0,00943 \\
(0,00801)\end{array}$ & & & & & 99,5 & $-0,47$ & 0,60 \\
\hline PIM & $\begin{array}{c}-0,00162 \\
(0,00139)\end{array}$ & $\begin{array}{l}0,796^{\star * *} \\
(0,0430)\end{array}$ & $\begin{array}{c}-0,0953^{\star *} \\
(0,0387)\end{array}$ & & & & & 88,7 & $-1,93$ & 2,25 \\
\hline OTQ & $\begin{array}{c}-0,00145^{\star *} \\
(0,000621)\end{array}$ & $\begin{array}{l}0,250^{\star * *} \\
(0,0185)\end{array}$ & $\begin{array}{l}0,597^{\star * *} \\
(0,0240)\end{array}$ & & & & & 97,3 & $-1,73$ & 2,07 \\
\hline CIK & $\begin{array}{c}-0,00316^{* * *} \\
(0,000974)\end{array}$ & $\begin{array}{l}0,0776^{* * *} \\
(0,0276)\end{array}$ & $\begin{array}{c}0,674^{* * *} \\
(0,0376)\end{array}$ & & & & & 93,2 & $-3,72$ & 2,86 \\
\hline KHK & $\begin{array}{c}-0,00127 \\
(0,00162)\end{array}$ & $\begin{array}{l}0,228^{\star * *} \\
(0,0612)\end{array}$ & $\begin{array}{l}0,389^{* * *} \\
(0,0734)\end{array}$ & & & & & 72,7 & $-1,52$ & 1,82 \\
\hline MKB & $\begin{array}{r}-0,00317^{*} \\
(0,00161)\end{array}$ & $\begin{array}{l}0,249^{\star * *} \\
(0,0698)\end{array}$ & $\begin{array}{l}0,388^{* * *} \\
(0,0871)\end{array}$ & & & & & 72,6 & $-3,74$ & 1,87 \\
\hline PIK & $\begin{array}{c}-0,00267^{* *} \\
(0,00126)\end{array}$ & $\begin{array}{l}0,130^{\star * *} \\
(0,0398)\end{array}$ & $\begin{array}{l}0,644^{* * *} \\
(0,0586)\end{array}$ & & & & & 89,6 & $-3,16$ & 2,28 \\
\hline RAR & $\begin{array}{c}-0,00211^{\star *} \\
(0,00102)\end{array}$ & $\begin{array}{l}0,354^{\star * *} \\
(0,0383)\end{array}$ & $\begin{array}{l}0,326^{\star * *} \\
(0,0470)\end{array}$ & & & & & 87,1 & $-2,51$ & 2,38 \\
\hline QUT & $\begin{array}{c}-0,00247^{* *} \\
(0,000999)\end{array}$ & $\begin{array}{c}0,0350 \\
(0,0359)\end{array}$ & $\begin{array}{l}0,557^{* * *} \\
(0,0396)\end{array}$ & $\begin{array}{c}-0,0505 \\
(0,0637)\end{array}$ & $\begin{array}{c}0,0324 \\
(0,0634)\end{array}$ & $\begin{array}{c}0,0415 \\
(0,0787)\end{array}$ & & 89,4 & $-2,93$ & 2,64 \\
\hline BFM & $\begin{array}{l}-0,00334^{\star * *} \\
(0,00100)\end{array}$ & $\begin{array}{l}0,144^{* * *} \\
(0,0342)\end{array}$ & $\begin{array}{l}0,526^{\star * *} \\
(0,0428)\end{array}$ & $\begin{array}{c}-0,0197 \\
(0,0738)\end{array}$ & $\begin{array}{c}0,0312 \\
(0,0982)\end{array}$ & $\begin{array}{c}0,00826 \\
(0,0898)\end{array}$ & & 90,3 & $-3,94$ & 2,22 \\
\hline GEG & $\begin{array}{c}-0,00285 \\
(0,00172)\end{array}$ & $\begin{array}{c}0,134^{*} \\
(0,0688)\end{array}$ & $\begin{array}{l}0,574^{\star * *} \\
(0,0704)\end{array}$ & $\begin{array}{c}0,0380 \\
(0,160)\end{array}$ & $\begin{array}{c}0,250^{*} \\
(0,131)\end{array}$ & $\begin{array}{c}-0,167 \\
(0,125)\end{array}$ & & 88,3 & $-3,36$ & 2,23 \\
\hline AEK & $\begin{array}{c}0,00107 \\
(0,00166)\end{array}$ & $\begin{array}{l}0,169^{* * *} \\
(0,0557)\end{array}$ & $\begin{array}{l}0,527^{\star * *} \\
(0,0754)\end{array}$ & $\begin{array}{c}-0,138 \\
(0,116)\end{array}$ & $\begin{array}{c}0,0200 \\
(0,110)\end{array}$ & $\begin{array}{c}0,0548 \\
(0,130)\end{array}$ & & 77,0 & 1,29 & 1,95 \\
\hline $\mathrm{COR}$ & $\begin{array}{l}0,00367^{* *} \\
(0,00166)\end{array}$ & $\begin{array}{l}0,440^{* * *} \\
(0,0527)\end{array}$ & $\begin{array}{l}0,182^{\star * *} \\
(0,0650)\end{array}$ & $\begin{array}{c}0,142 \\
(0,101)\end{array}$ & $\begin{array}{c}-0,0635 \\
(0,122)\end{array}$ & $\begin{array}{c}-0,172 \\
(0,124)\end{array}$ & & 79,4 & 4,49 & 2,15 \\
\hline $\mathrm{COK}$ & $\begin{array}{c}-0,000839 \\
(0,000602)\end{array}$ & $\begin{array}{c}0,0205 \\
(0,0176)\end{array}$ & $\begin{array}{l}0,903^{\star * *} \\
(0,0191)\end{array}$ & $\begin{array}{c}0,00634 \\
(0,0441)\end{array}$ & $\begin{array}{c}0,0754 \\
(0,0516)\end{array}$ & $\begin{array}{c}-0,0457 \\
(0,0504)\end{array}$ & & 98,6 & $-1,00$ & 1,07 \\
\hline ERK & $\begin{array}{l}-0,00464^{* * *} \\
(0,00131)\end{array}$ & $\begin{array}{l}0,235^{* * *} \\
(0,0668)\end{array}$ & $\begin{array}{l}0,405^{\star * *} \\
(0,0690)\end{array}$ & $\begin{array}{c}0,0348 \\
(0,114)\end{array}$ & $\begin{array}{c}-0,0585 \\
(0,0953)\end{array}$ & $\begin{array}{c}-0,0664 \\
(0,0936)\end{array}$ & & 81,5 & $-5,43$ & 1,54 \\
\hline AEN & $\begin{array}{c}-0,00349 \\
(0,00222)\end{array}$ & $\begin{array}{c}0,0571 \\
(0,0631)\end{array}$ & $\begin{array}{l}0,330^{* * *} \\
(0,0646)\end{array}$ & $\begin{array}{l}0,906^{\star * *} \\
(0,129)\end{array}$ & $\begin{array}{l}0,272^{* *} \\
(0,116)\end{array}$ & $\begin{array}{l}-0,421^{\star * *} \\
(0,115)\end{array}$ & & 51,8 & $-4,10$ & 1,88 \\
\hline KHA & $\begin{array}{c}-0,00544^{* * *} \\
(0,00168)\end{array}$ & & $\begin{array}{l}0,892^{* * *} \\
(0,0678)\end{array}$ & & & & $\begin{array}{l}-0,221^{\star *} \\
(0,104)\end{array}$ & 73,8 & $-6,34$ & 2,76 \\
\hline MKE & $\begin{array}{c}-0,00173 \\
(0,00199)\end{array}$ & & $\begin{array}{l}0,718^{* * *} \\
(0,0656)\end{array}$ & & & & & 71,5 & $-2,06$ & 1,65 \\
\hline PIU & $\begin{array}{l}-0,00209^{* * *} \\
(0,000769)\end{array}$ & & $\begin{array}{l}0,886^{* * *} \\
(0,0226)\end{array}$ & & & & & 92,5 & $-2,48$ & 2,37 \\
\hline GEM & $\begin{array}{r}-0,00299^{*} \\
(0,00173)\end{array}$ & & $\begin{array}{l}0,683^{* * *} \\
(0,0496)\end{array}$ & & & & & 63,9 & $-3,53$ & 3,11 \\
\hline
\end{tabular}


A 2. táblázat folytatása

\begin{tabular}{|c|c|c|c|c|c|c|c|c|c|c|c|}
\hline \multirow[t]{2}{*}{ Alap } & \multirow[t]{2}{*}{ Alfa } & \multicolumn{7}{|c|}{ Béta } & \multirow[t]{2}{*}{$R^{2}$} & \multicolumn{2}{|c|}{ Éves alfa Költség } \\
\hline & & BUX & CETOPTR & SP500TR & EUR & PLN & CZK & USD & & százalék & \\
\hline \multicolumn{12}{|c|}{ B) AZ UTOLSÓ ÖT ÉV } \\
\hline ALI & $\begin{array}{l}-0,00131^{\star * *} \\
(0,000378)\end{array}$ & $\begin{array}{l}0,972^{* * *} \\
(0,0139)\end{array}$ & $\begin{array}{c}0,0183 \\
(0,0152)\end{array}$ & & & & & & 99,7 & $-1,56$ & 1,88 \\
\hline $\mathrm{CII}$ & $\begin{array}{c}-0,00207^{\star * *} \\
(0,000165)\end{array}$ & $\begin{array}{c}0,985^{* * *} \\
(0,00406)\end{array}$ & $\begin{array}{l}0,00794^{*} \\
(0,00470)\end{array}$ & & & & & & 100,0 & $-2,45$ & 2,68 \\
\hline ERH & $\begin{array}{c}-0,00164^{\star * *} \\
(0,000462)\end{array}$ & $\begin{array}{l}0,956^{* * *} \\
(0,0119)\end{array}$ & $\begin{array}{c}-0,00831 \\
(0,0133)\end{array}$ & & & & & & 99,7 & $-1,95$ & 1,04 \\
\hline $\mathrm{KHN}$ & $\begin{array}{l}-0,000631 \\
(0,000439)\end{array}$ & $\begin{array}{l}0,974^{\star * *} \\
(0,0103)\end{array}$ & $\begin{array}{l}0,00318 \\
(0,0129)\end{array}$ & & & & & & 99,7 & $-0,76$ & 1,98 \\
\hline OTT & $\begin{array}{l}-0,000442 \\
(0,000347)\end{array}$ & $\begin{array}{l}0,991^{* * *} \\
(0,0133)\end{array}$ & $\begin{array}{l}-0,00549 \\
(0,00697)\end{array}$ & & & & & & 99,6 & $-0,53$ & 0,60 \\
\hline PIM & $\begin{array}{l}-0,000404 \\
(0,000567)\end{array}$ & $\begin{array}{l}0,989^{* * *} \\
(0,0123)\end{array}$ & $\begin{array}{c}0,0192 \\
(0,0227)\end{array}$ & & & & & & 99,1 & $-0,48$ & 2,25 \\
\hline OTQ & $\begin{array}{c}-0,00166^{\star * *} \\
(0,000592)\end{array}$ & $\begin{array}{l}0,184^{\star * *} \\
(0,0167)\end{array}$ & $\begin{array}{l}0,699^{* * *} \\
(0,0230)\end{array}$ & & & & & & 98,7 & $-1,97$ & 2,07 \\
\hline CIK & $\begin{array}{c}-0,00300^{\star * *} \\
(0,000507)\end{array}$ & $\begin{array}{l}-0,0124 \\
(0,0140)\end{array}$ & $\begin{array}{l}0,812^{\star * *} \\
(0,0151)\end{array}$ & & & & & & 98,9 & $-3,54$ & 2,86 \\
\hline KHK & $\begin{array}{c}-0,00312^{\star * *} \\
(0,000939)\end{array}$ & $\begin{array}{c}-0,0648^{* * *} \\
(0,0228)\end{array}$ & $\begin{array}{l}0,865^{\star * *} \\
(0,0311)\end{array}$ & & & & & & 95,9 & $-3,68$ & 1,82 \\
\hline $\mathrm{MKB}$ & $\begin{array}{c}-0,00379^{* *} \\
(0,00168)\end{array}$ & $\begin{array}{c}0,0464 \\
(0,0532)\end{array}$ & $\begin{array}{l}0,706^{\star * *} \\
(0,0645)\end{array}$ & & & & & & 84,9 & $-4,45$ & 1,87 \\
\hline PIK & $\begin{array}{c}-0,00198^{\star *} \\
(0,000812)\end{array}$ & $\begin{array}{c}0,0332 \\
(0,0243)\end{array}$ & $\begin{array}{l}0,923^{\star * *} \\
(0,0276)\end{array}$ & & & & & & 97,6 & $-2,35$ & 2,28 \\
\hline RAR & $\begin{array}{l}-0,00230^{*} \\
(0,00133)\end{array}$ & $\begin{array}{l}0,183^{\star * *} \\
(0,0378)\end{array}$ & $\begin{array}{l}0,550^{\star * *} \\
(0,0574)\end{array}$ & & & & & & 84,1 & $-2,73$ & 2,38 \\
\hline QUT & $\begin{array}{l}-0,00191 \\
(0,00163)\end{array}$ & $\begin{array}{c}0,0695 \\
(0,0642)\end{array}$ & $\begin{array}{l}0,576^{\star * *} \\
(0,0777)\end{array}$ & & $\begin{array}{l}-0,166 \\
(0,176)\end{array}$ & $\begin{array}{c}0,0697 \\
(0,0785)\end{array}$ & $\begin{array}{l}0,445^{\star *} \\
(0,217)\end{array}$ & & 89,4 & $-2,27$ & 2,64 \\
\hline BFM & $\begin{array}{l}-0,00275^{\star * *} \\
(0,000771)\end{array}$ & $\begin{array}{c}0,0148 \\
(0,0202)\end{array}$ & $\begin{array}{l}0,709^{\star * *} \\
(0,0409)\end{array}$ & & $\begin{array}{l}0,0847 \\
(0,107)\end{array}$ & $\begin{array}{l}0,232^{*} \\
(0,120)\end{array}$ & $\begin{array}{l}-0,0349 \\
(0,0692)\end{array}$ & & 96,7 & $-3,25$ & 2,22 \\
\hline GEG & $\begin{array}{c}-0,00381^{\star * *} \\
(0,00130)\end{array}$ & $\begin{array}{c}0,0231 \\
(0,0358)\end{array}$ & $\begin{array}{l}0,637^{\star * *} \\
(0,0685)\end{array}$ & & $\begin{array}{c}-0,376^{\star *} \\
(0,177)\end{array}$ & $\begin{array}{c}0,556^{* * *} \\
(0,179)\end{array}$ & $\begin{array}{l}0,0533 \\
(0,124)\end{array}$ & & 92,5 & $-4,48$ & 2,23 \\
\hline AEK & $\begin{array}{c}-0,00104 \\
(0,000778)\end{array}$ & $\begin{array}{l}-0,0303 \\
(0,0263)\end{array}$ & $\begin{array}{l}0,893^{\star * *} \\
(0,0336)\end{array}$ & & $\begin{array}{l}-0,0764 \\
(0,0912)\end{array}$ & $\begin{array}{l}0,241^{* * *} \\
(0,0637)\end{array}$ & $\begin{array}{c}0,0191 \\
(0,0841)\end{array}$ & & 98,2 & $-1,24$ & 1,95 \\
\hline COR & $\begin{array}{l}0,00509^{* *} \\
(0,00232)\end{array}$ & $\begin{array}{l}0,265^{\star * *} \\
(0,0681)\end{array}$ & $\begin{array}{l}0,187^{\star *} \\
(0,0790)\end{array}$ & & $\begin{array}{l}0,0990 \\
(0,190)\end{array}$ & $\begin{array}{c}0,218 \\
(0,160)\end{array}$ & $\begin{array}{l}-0,221 \\
(0,220)\end{array}$ & & 70,7 & 6,28 & 2,15 \\
\hline $\mathrm{COK}$ & $\begin{array}{l}-0,00110^{\star} \\
(0,000630)\end{array}$ & $\begin{array}{c}-0,00846 \\
(0,0168)\end{array}$ & $\begin{array}{l}0,883^{\star * *} \\
(0,0279)\end{array}$ & & $\begin{array}{l}-0,0702 \\
(0,0825)\end{array}$ & $\begin{array}{l}0,173^{\star *} \\
(0,0819)\end{array}$ & $\begin{array}{c}-0,00280 \\
(0,0604)\end{array}$ & & 98,4 & $-1,31$ & 1,07 \\
\hline ERK & $\begin{array}{c}-0,00443^{\star * *} \\
(0,00149)\end{array}$ & $\begin{array}{c}0,0139 \\
(0,0347)\end{array}$ & $\begin{array}{l}0,668^{* * *} \\
(0,0604)\end{array}$ & & $\begin{array}{c}-0,314^{\star *} \\
(0,133)\end{array}$ & $\begin{array}{l}0,321^{\star *} \\
(0,147)\end{array}$ & $\begin{array}{l}0,0499 \\
(0,109)\end{array}$ & & 91,3 & $-5,19$ & 1,54 \\
\hline AEN & $\begin{array}{c}0,00257 \\
(0,00364)\end{array}$ & $\begin{array}{c}0,0956 \\
(0,0955)\end{array}$ & $\begin{array}{l}0,291^{\star * *} \\
(0,0992)\end{array}$ & & $\begin{array}{c}0,719^{* * *} \\
(0,178)\end{array}$ & $\begin{array}{l}0,536^{* *} \\
(0,254)\end{array}$ & $\begin{array}{c}-0,497^{* * *} \\
(0,185)\end{array}$ & & 45,5 & 3,13 & 1,88 \\
\hline KHA & $\begin{array}{c}-0,00438^{\star * *} \\
(0,00140)\end{array}$ & & & $\begin{array}{l}0,927^{\star * *} \\
(0,0339)\end{array}$ & & & & $\begin{array}{l}-0,132^{\star} \\
(0,0686)\end{array}$ & 87,4 & $-5,13$ & 2,76 \\
\hline MKE & $\begin{array}{l}-0,000925 \\
(0,00206)\end{array}$ & & & $\begin{array}{l}0,705^{\star * *} \\
(0,0690)\end{array}$ & & & & & 69,9 & $-1,10$ & 1,65 \\
\hline PIU & $\begin{array}{l}-0,00264^{\star * *} \\
(0,000946)\end{array}$ & & & $\begin{array}{l}0,922^{* * *} \\
(0,0477)\end{array}$ & & & & & 92,3 & $-3,12$ & 2,37 \\
\hline GEM & $\begin{array}{l}-0,00216 \\
(0,00157)\end{array}$ & & & $\begin{array}{l}0,807^{\star * *} \\
(0,0623)\end{array}$ & & & & & 79,1 & $-2,56$ & 3,11 \\
\hline
\end{tabular}

Megjegyzés: a Newey-West-féle heteroszkedaszticitás- és autokorreláció-konzisztens standard hibák zárójelben (1 periódus késleltetéssel számolva).

${ }^{* * *} 1$ százalékos, ${ }^{* *} 5$ százalékos, ${ }^{\star} 10$ százalékos szinten szignifikáns. 
korrigáltuk. A 2. táblázat A) részén a K\&H Amerika alapnál (KHA) az USD teljeshozamindex -0,221-es együtthatója például azt jelenti, hogy az alap az USD-devizakockázatnak a teljes eszközértékéhez képest 22,1 százalékát fedezi. A jelen tanulmányban nem közölt további becslés szerint a devizakitettséggel való korrekció hatása az alfára csekély, és e korrekció nélkül is hasonló eredményeket kapnánk.

Az utóbbi időszakban sok alap szorosabban követi az indexeket, mint korábban. Erre utal, hogy 2. táblázat csak az utolsó öt évet mutató $B$ ) részén az átlagos $R^{2} 90,4$ százalék, míg a korábbi időszakot is magában foglaló teljes mintában 84,3 százalék. A táblázat $B$ ) részén az is látható, hogy nem csak a nevükben is indexkövető magyar alapok követik szorosan az adott indexet (mindegyik esetében 99 százalék feletti az $R^{2}$ ). A névleg aktív KKE-alapok közül négy esetében 98 százalék feletti az $R^{2}$, további két alapnál pedig a 95-98 százalék közötti tartományban van. Az ilyen alapokat nevezhetjük - Petajisto [2013] terminológiájával élve - titkolt indexkövetőnek (closet indexer).

Ha a teljes mintát nézzük, akkor 5 százalékos szinten 11 alapnak szignifikánsan negatív az alfája, és csak egynek szignifikánsan pozitív. Ha igaz lenne, hogy $\alpha$ értéke 0, akkor a 24 alap 5 százalékánál, azaz körülbelül egy-két esetben kellene csak 5 százalékos szinten szignifikáns együtthatót találnunk. A 24 alapból csak négynek pozitív az alfája, de abból is csak egy statisztikailag szignifikáns. Ha csak az utolsó öt évre koncentrálunk, akkor a 2. táblázat B) részén azt látjuk, hogy a 24-ből csak két alapnak pozitív az alfája, de csak egy szignifikáns 5 százalékos szinten, a 22 negatívból pedig 13 szignifikáns 5 százalékos szinten. Összességében tehát az alapok több mint felére egyértelmüen visszautasithatjuk azt a feltevést, hogy $\alpha$ értéke 0 .

Csak egy alap van, a Concorde Részvény Befektetési Alap, amelyre 5 százalékos szignifikanciaszint mellett kijelenthetjük, hogy az $\alpha$ pozitív. Viszont 24 alap esetében ez összeegyeztethető a statisztikai hibával, tehát még ennek az egy alapnak az esetében sem állithatjuk biztosan, hogy olyan befektetési stratégiával rendelkezik, amelynek segítségével jobban teljesít a referenciahozamnál. Az alap kezelője a sikert azzal magyarázza, ${ }^{14}$ hogy nem próbálják a CETOP-ot követni, hanem jelentősen eltérnek attól (fóleg az utóbbi öt évben). A 2. táblázat B) részén látható, hogy az alap $R^{2}$-e 70,7 százalékkal tényleg az egyik legalacsonyabb az alapok közül, tehát tényleg nem követi szorosan a CETOP és a BUX indexet. A jelen cikkben nem közölt további regressziók arra utalnak, hogy például a román piacot túlsúlyozzák a CETOP-hoz képest, de ez is csak kis részét magyarázza a magas alfának.

Érdemes megjegyezni, hogy ha a hivatalos CETOP indexet használjuk az általam számolt CETOPTR index helyett, akkor a hat határidős ügyletet nem használó KKE-alap esetében a tényleges átlagos $-2,75$ százalékos éves $\alpha$ helyett $-1,39$ százalékot kapunk. Ennek az az oka, hogy utóbbi esetben az alapok hozamánál figyelembe vesszük az osztalékjövedelmet, az index hozamánál viszont nem, így úgy tünhet, hogy az alapok jobban teljesítenek az indexhez képest, mint valójában.

A 24 alap átlagos éves alfája a teljes mintán -2,11 százalék (az utolsó 5 év során -1,95 százalék), az átlagos kezelési költségük 2,05 százalék. Jól látható, hogy a két szám hasonló. Itt hozzá kell tenni, hogy a kezelési költség a legutolsó évre vonatkozik, és nem

\footnotetext{
${ }^{14} \mathrm{http}: / /$ www.tozsdeforum.hu/kulso-blogok/alapblog/a-concorde-reszveny-alap-titka-4580.
} 
az egész sokéves megfigyelési idő alatti átlagos kezelési költség, amelynek kiszámításához sajnos nem találtunk elegendő adatot. ${ }^{15}$ Ez nem akkora gond, ugyanis a kezelési költségek nagyon keveset változnak évről évre, így vehetjük egy adott év kezelési költségét a többéves átlag helyett (lásd Elton és szerzőtársai [1993]).

Ha tényleg a kezelési költségek okozzák a negatív alfát, akkor igaznak kell lennie, hogy a magasabb kezelési költségekkel dolgozó alapok alfája kisebb, ugyanis a költségek levonása után kevesebb marad a befektetőknek. A 2. ábrán látható az éves kezelési költség (vízszintes tengely) és az éves $\alpha$ (függőleges tengely) mind a 24 alapra. Az adatok a 2. táblázatból származnak. Ránézésre is látható, hogy minél nagyobb a kezelési költség, annál kisebb az $\alpha$. Hogy ezt formálisan is megmutassuk, Blake és szerzötársai [1993] munkáját követve a becsült évesített alfát regresszáljuk az éves kezelési költségre az alábbi egyenlet szerint:

$\hat{\alpha}_{i}=\gamma+\delta \times$ költség $_{i}+\varepsilon_{i}$,

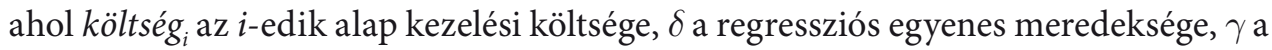
konstans, $\varepsilon_{i}$ pedig a hibatag.

2. ábra

Alapok teljesítménye és a kezelési költség a teljes mintán

Éves alfa (százalék)

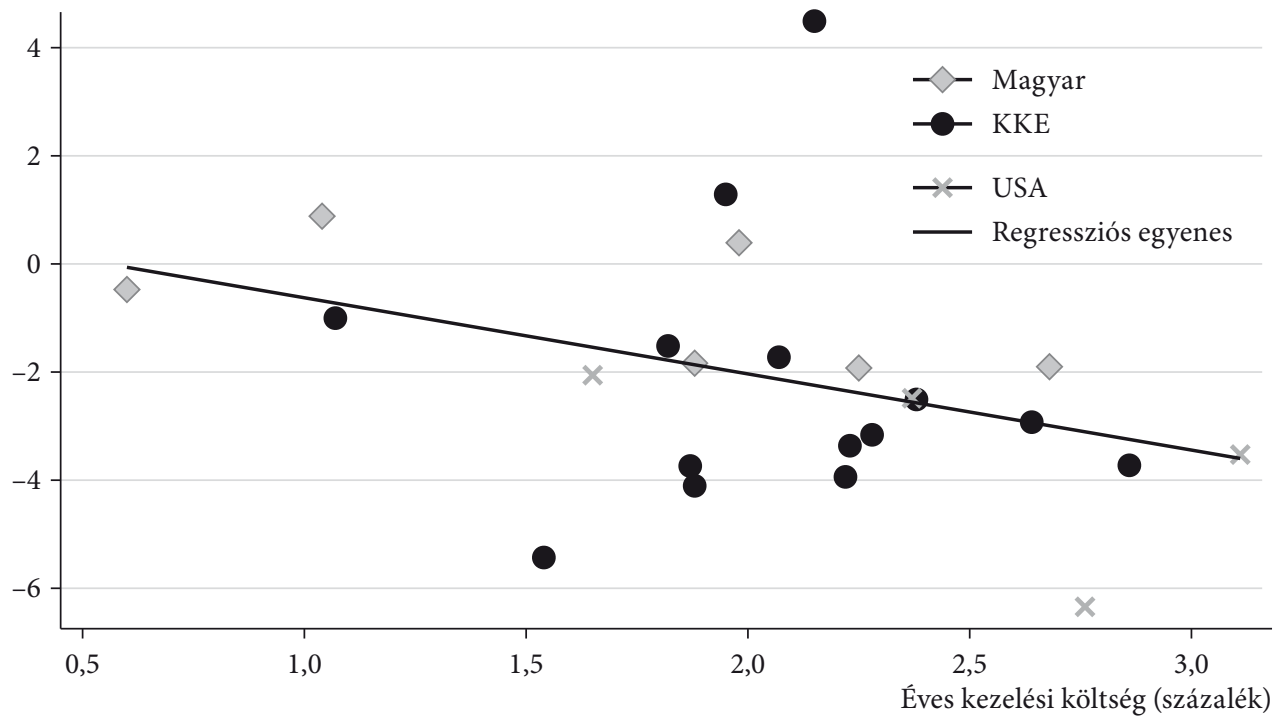

Az alapok teljesítménye és kezelési költségük közötti kapcsolatot bemutató 3. táblá$z a t A)$ részében látható e tanulmány fö eredménye.

${ }^{15}$ A Magyar Nemzeti Bank megosztotta velem specifikus évek költségeinek táblázatát (2005-2009, 2013, 2015). Az egyes alapokra az átlagos és mediánköltségek (a 2005, 2007, 2009, 2013, 2015 idősorban) gyakorlatilag ugyanazok, mint a legutóbbi költségek: a korreláció 92, illetve 95 százalék. 
3. táblázat

Az alapok teljesítménye és kezelési költségük közötti összefüggés

\begin{tabular}{lcccc}
\hline Minta & $\begin{array}{c}\text { Az alapok } \\
\text { száma }\end{array}$ & Delta & Gamma & $R^{2}$ \\
\cline { 3 - 4 } & & \multicolumn{2}{c}{ százalék } \\
\hline
\end{tabular}

\section{A) TELJES MINTA}

\begin{tabular}{|c|c|c|c|c|}
\hline Összes alap & 24 & $\begin{array}{c}-1,409^{\star * *} \\
(0,487)\end{array}$ & $\begin{array}{l}0,784 \\
(1,10)\end{array}$ & 13,1 \\
\hline USA nélkül & 21 & $\begin{array}{l}-1,031^{\star} \\
(0,512)\end{array}$ & $\begin{array}{c}-0,220 \\
(1,14)\end{array}$ & 6,4 \\
\hline Derivatívát nem használ & 15 & $\begin{array}{l}-1,466^{\star * *} \\
(0,350)\end{array}$ & $\begin{array}{c}1,06 \\
(0,860)\end{array}$ & 47,1 \\
\hline $\begin{array}{l}\text { USA nélkül és derivatívát } \\
\text { nem használ }\end{array}$ & 12 & $\begin{array}{l}-1,503^{\star * *} \\
(0,453)\end{array}$ & $\begin{array}{c}1,20 \\
(1,02)\end{array}$ & 42,3 \\
\hline Passzív $\left(R^{2}>90\right)$ & 8 & $\begin{array}{l}-1,213^{* * *} \\
(0,268)\end{array}$ & $\begin{array}{c}0,252 \\
(0,320)\end{array}$ & 60,5 \\
\hline Magyar (indexkövető) & 6 & $\begin{array}{l}-1,003 \\
(0,510)\end{array}$ & $\begin{array}{l}0,934 \\
(1,08)\end{array}$ & 38,3 \\
\hline \multicolumn{5}{|l|}{ B) AZ UTOLSÓ ÖT ÉV } \\
\hline Összes alap & 24 & $\begin{array}{l}-0,817^{*} \\
(0,424)\end{array}$ & $\begin{array}{c}-0,268 \\
(1,01)\end{array}$ & 3,7 \\
\hline USA nélkül & 20 & $\begin{array}{l}-0,436 \\
(0,509)\end{array}$ & $\begin{array}{c}-0,882 \\
(1,06)\end{array}$ & 0,9 \\
\hline Derivatívát nem használ & 15 & $\begin{array}{c}-0,740^{\star *} \\
(0,275)\end{array}$ & $\begin{array}{l}-0,693 \\
(0,694)\end{array}$ & 16,2 \\
\hline $\begin{array}{l}\text { USA nélkül és derivatívát } \\
\text { nem használ }\end{array}$ & 12 & $\begin{array}{l}-0,733^{*} \\
(0,334)\end{array}$ & $\begin{array}{l}-0,756 \\
(0,766)\end{array}$ & 13,4 \\
\hline Passzív $\left(R^{2}>90 \%\right)$ & 16 & $\begin{array}{l}-0,749^{*} \\
(0,394)\end{array}$ & $\begin{array}{l}-0,923 \\
(0,886)\end{array}$ & 10,4 \\
\hline Passzív $\left(R^{2}>95 \%\right)$ & 13 & $\begin{array}{c}-0,808^{\star *} \\
(0,284)\end{array}$ & $\begin{array}{l}-0,393 \\
(0,524)\end{array}$ & 23,2 \\
\hline Magyar (indexkövető) & 6 & $\begin{array}{l}-0,332 \\
(0,498)\end{array}$ & $\begin{array}{c}-0,712 \\
(0,847)\end{array}$ & 9,8 \\
\hline
\end{tabular}

Megjegyzés: a Huber-White-féle heteroszkedaszticitás-konzisztens standard hibák zárójelben. ${ }^{* * *} 1$ százalékos, ${ }^{\star *} 5$ százalékos, ${ }^{\star} 10$ százalékos szinten szignifikáns.

A $\delta$ együttható a harmadik oszlopban mutatja a befektetési alap teljesítményének költségérzékenységét. A teljes mintán $\delta=-1,409$, ami azt jelenti, hogy ha egy alap 1 százalékponttal magasabb kezelési költséget számol fel, akkor a teljesítménye (Jensen alfája) átlagosan 1,409 százalékponttal romlik. Ez az eredmény 1 százalékos szinten szignifikánsan különbözik 0-tól. Másfelől viszont az együttható nem különbözik szignifikánsan -1-től, amit elméletben várunk, ha a piac valóban hatékony. Sőt az eredmény igen hasonló a Carhart [1997] által amerikai részvényalapoknál mért 
-1,54-os együtthatóhoz (lásd a szerző 5. táblázatát). Blake és szerzötársai [1993] amerikai kötvényalapokra szintén -1-hez közeli együtthatót kapnak (lásd a szerzők 11. táblázatát). Az is szembetűnő, hogy $\gamma$ nem szignifikánsan különbözik 0 -tól, tehát nem lehet visszautasítani azt a feltevést, hogy egy hipotetikus, 0 költséggel dolgozó alap pontosan úgy teljesít, mint ha az indexekbe fektettünk volna közvetlenül. Az $R^{2} 13,1$ százalék, tehát a kezelési költség nem mindegyik alapnál magyarázza jól a teljesítményt. Ennek oka lehet, hogy az alapok teljesítményében más tényezők is közrejátszhatnak, és természetesen a szerencse is. A derivatívákat nem használó, egyszerübben müködő alapoknál az $R^{2}$ értéke 47,1 százalék, ezeknél az alapoknál a kezelési költség önmagában megmagyarázza az alapok teljesítményének közel felét. Az USA-alapok nélkül is hasonló $\delta$ együtthatókat kapunk.

Az ötödik sorban csak azok az alapok szerepelnek, amelyek passzívan követik az indexeket. Azok az alapok kerülnek ide, amelyek $R^{2}$-értéke a 2. táblázatban legalább 90 százalék, azaz az indexek hozama erősen magyarázza az alap hozamát. Ezek esetében a költség még erősebben magyarázza az alfát, az $R^{2}$ igen magas, 74,2 százalék. Ennek oka, hogy ezek az alapok gyakorlatilag ugyanazt a portfóliót tartják, mint az indexek, így teljesítményük csupán a felszámolt kezelési költség miatt nem is térhet el az indexek teljesítményétől.

A 3. táblázat $A$ ) részében a magyar alapok $\delta$ együtthatójának értéke -1,003, de a hat alap esetében az eredmény nem szignifikáns. Itt kell megjegyezni, hogy a mintában egyedül a magyar alapok azok, amelyek nevükben is vállalják, hogy passzív indexkövető stratégiát folytatnak.

A 3. táblázat B) része tartalmazza az utolsó öt év adatai alapján becsült alfákra vonatkozó eredményeket. Az összes alapot használva, a $\delta$ együttható $-0,817$, amely 10 százalékos szinten szignifikáns, és egyben hibahatáron belül van a -1-hez képest. A gyengébb szignifikancia oka minden bizonnyal, hogy rövid adatsor esetén az $\alpha$ pontatlanabbul becsülhetö, ezért az $\alpha$ és a költségek közötti összefüggés sem mérhető pontosan. Ezt illusztrálja az alacsony, 3,7 százalékos $R^{2}$. Ez az eredmény is alátámasztja, hogy milyen fontos hosszú adatsorokat használni a hasonló tanulmányokban. Az alapok többi alcsoportjában a teljes mintához hasonló eredményeket látunk. Külön csak arra érdemes felhívni a figyelmet, hogy az utolsó öt évben a 2. táblázatban mérhető magasabb $R^{2}$-ek miatt itt a passzív alapoknak két definíciója is szerepel: 90 százalék és 95 százalék feletti $R^{2}$. Jól látható, hogy minél passzívabb az alap, annál jobban magyarázza az alap teljesítményét a kezelési költség.

Mivel a CETOPTR index kiszámítása igen munkaigényes, megvizsgáljuk, hogy esetleg egy másik indexszel hasonló eredményre jutnánk-e. Így a CETOPTR helyett a Bécsi Tőzsde által számolt CECETR indexet használjuk, amely teljeshozam-indexként is elérhetö, igaz csak rövidebb időszakra. A CETOP a KKE-alapok esetén fontos, így azt vizsgálom, hogy ezek becsült $\alpha$-ja mennyiben függ attól, hogy melyik indexet használjuk. A hozamadatokat 2007 februárjától vizsgálom, amikortól mindkét index rendelkezésre áll.

A 4. táblázat tartalmazza az eredményeket. A harmadiktól a hatodik számoszlopig a CETOPTR indexszel számolt regresszió eredményei láthatók, a hetediktől a tizedik számoszlopig a CECETR indexszel számolt regresszió eredményei. A számolt 


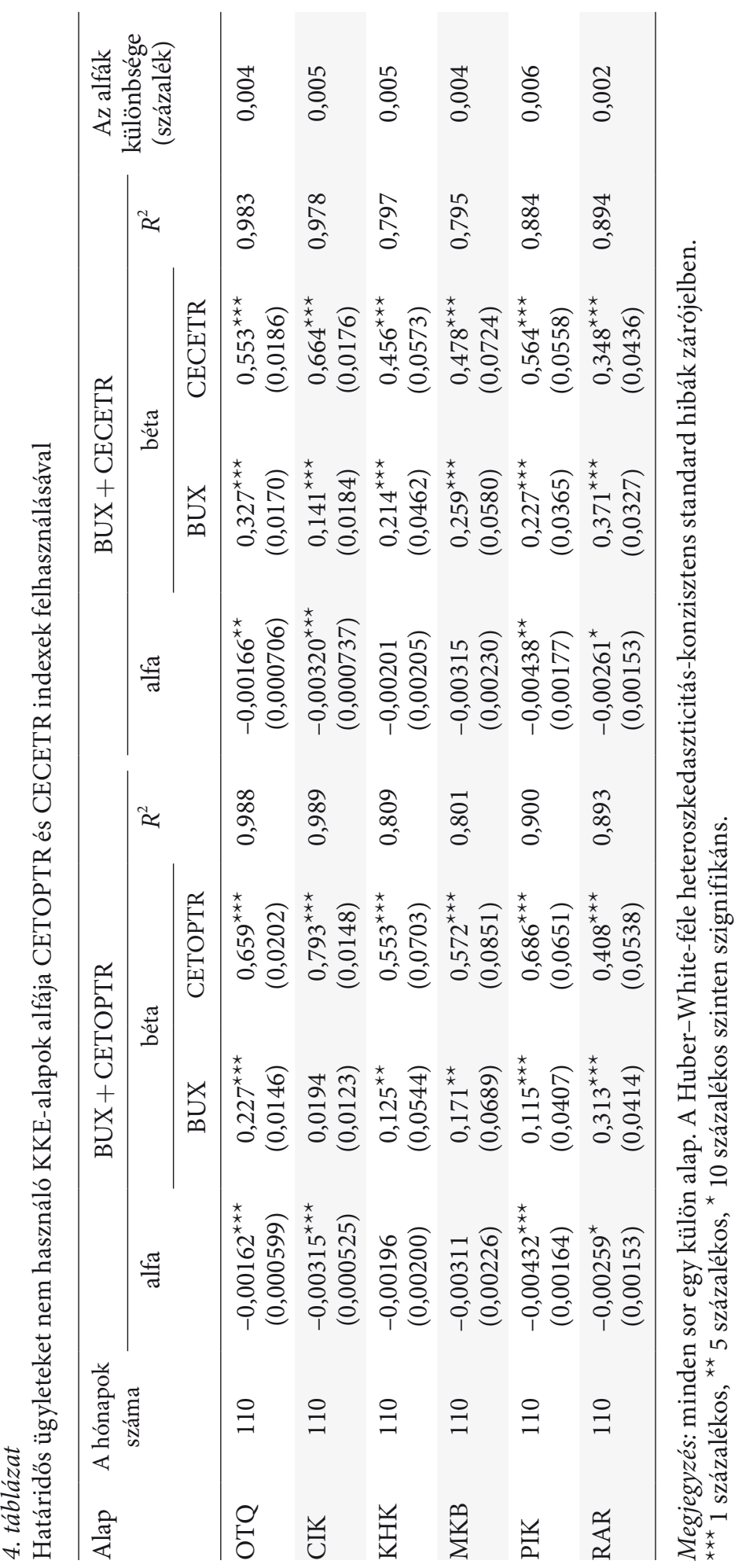


alfák közötti különbség a tizedik számoszlopban látható, és minimális. Tipikusan 0,004 százalék a különbség, ez éves szinten 0,048 százalék, ami a -2 százalék körüli éves alfákhoz képest elhanyagolható. Az $\mathrm{R}^{2}$ valamivel magasabb a CETOPTR indexet használva, talán mert ezt próbálják követni a portfóliókezelök és nem a CECETR indexet. A nagy különbség a bétákban van. Ha CECETR-t használunk CETOPTR helyett, akkor a BUX bétája megnövekszik. Ennek oka az, hogy CETOPTR-ben magasabb a magyar részvények súlya, így ha azt CECETR-re cseréljük, akkor a BUX megnövekedett bétája veszi át a szerepét.

Annak ellenőrzésére, hogy CETOPTR tényleg helyettesíthetö-e a CECETR és BUX indexek valamilyen keverékével, regresszálom a CETOPTR-hozamokat a CECETR és BUX indexek hozamaira: ${ }^{16}$

$$
\begin{aligned}
r_{\mathrm{CETOPTR}, t}^{e} & =(-0,000 \pm 0,0066) \%+(0,837 \pm 0,017) \cdot r_{\mathrm{CECETR}, t}^{e}+ \\
& +(0,153 \pm 0,017) \cdot r_{\mathrm{BUX}, t}^{e}+\varepsilon_{t} .
\end{aligned}
$$

Eredményül $R^{2} 98,8$ százaléknak adódott. Tehát a CETOPTR index nagyon jól leírható a CECETR és a BUX indexek körülbelül 83,7-15,3 százalékos keverékével. ${ }^{17}$ A hozamok közötti szintbeli különbség (azaz a konstans a fenti egyenletben) nem szignifikáns. Tehát ugyanolyan jól értékelhető a KKE-alapok teljesítménye a CETOPTR indexszel, mint a CECETR indexszel, a hivatalos CETOP index az osztalékok hiányában viszont alkalmatlan erre.

\section{Következtetések}

A jelen tanulmány megmutatja, hogy a magasabb kezelési költség a magyar befektetési alapoknál sem párosul jobb befektetési teljesítménnyel. Az indexet a magas költségű alapok sem tudják túlteljesíteni, a kezelési költségek így csökkentik a befektetőknek juttatott hozamot. A legtöbb alap rosszabb hozamot ad a befektetőknek, mint ha azok passzívan az adott régió tőzsdeindexét követték volna. Ez felhívja arra a figyelmet, hogy fontos lenne a kezelési költségeket leszorítani. Ennek fontos lépcsője lehet a MIFID II. irányelvek hazai bevezetése, hogy a befektetők tudják, hogy a magas kezelési költségből mennyit kap a közvetítő, aki az adott alapot ajánlja.

Emellett az elemzés azt is megmutatja, hogy a Budapesti Értéktőzsde által számolt CETOP nem megfelelö referenciamutató a közép-kelet-európai alapoknál, mert nem tartalmazza az osztalékot. Egyfelöl hasznos lenne a CETOP indexet mind ár-, mind teljeshozam-indexként is közzétenni, ahogy ez a CECE és az S\&P500 index esetén is történik. Másfelöl fontos lenne a befektetési alapokat úgy szabályozni, hogy a referenciahozamot tényleg referenciahozamként lehessen értelmezni. Ez akkor valósul meg, ha a referenciahozamot kötelező úgy számolni, hogy az a valós befektetésnek

\footnotetext{
${ }^{16}$ A Newey-West-féle heteroszkedaszticitás- és autokorreláció-konzisztens standard hibákat 1 periódus késleltetéssel számoltam.

${ }^{17}$ A két szám nem adódik össze 100 százalékra. Ezt úgy kell érteni, hogy a fennmaradó részt kockázatmentes forinteszközbe kell fektetni.
} 
megfelelö pénzügyi eszközöket és régiókat fedje le a használt referenciaindexek megfelelő megválasztásával és súlyozásával. Továbbá, csak olyan referenciaindexeket lehessen használni, amelyek tartalmazzák az osztalékokat.

\section{Hivatkozások}

Blake, C. R.-Elton, E. J.-Gruber, M. J. [1993]: The Performance of Bond Mutual Funds. Journal of Business, Vol. 66. No. 3. 371-404. o. https://doi.org/10.1086/296609.

BóTA GÁвоR [2014]: A magyarországi befektetési alapok teljesítményét meghatározó tényezők vizsgálata. Hitelintézeti Szemle, 13. évf. 2. sz. 147-163. o.

Carhart, M. M. [1997]: On Persistence in Mutual Fund Performance. Journal of Finance, Vol. 52. No. 1. 57-82. o. https://doi.org/10.2307/2329556.

Elton, E. J.-Gruber, M. J.-Das, S.-Hlavka, M. [1993]: Efficiency with Costly Information: A Reinterpretation of Evidence from Managed Portfolios. Review of Financial Studies, Vol. 6. No. 1. 1-22. o. https://doi.org/10.1093/rfs/6.1.1.

Erdős PÉTER-Ormos Minály [2009]: Return Calculation Methodology: Evidence from the Hungarian Mutual Fund Industry. Acta Oeconomica, Vol. 59. No. 4. 391-409. o.

FAMA, E. [1970]: Efficient Capital Markets: A Review of Theory and Empirical Work. Journal of Finance, Vol. 25. No. 2. 383-417. o. https://doi.org/10.2307/2325486.

Jensen, M. C. [1968]: The Performance of Mutual Funds in the Period 1945-1964. Journal of Finance, Vol. 23. No. 2. 389-416. o. https://doi.org/10.2307/2325404.

Petajisto, A. [2013]: Active Share and Mutual Fund Performance. Financial Analysts Journal, Vol. 69. No. 4. 73-93. o. https://doi.org/10.2469/faj.v69.n4.7.

Radnai Márton-Szatmári Alexandra [2006]: A magyar pénzpiaci alapok összehasonlító elemzése. Közgazdasági Szemle, 53. évf. 5. sz. 389-407. o.

SzATMÁRI AleXAndRa [2006]: Magyar részvény és kötvény befektetési alapok teljesítményének értékelése. Pro Scientia aranyérmesek VIII. tudományos konferenciája, PSAT, Budapest, 25-30. o. http://psat.hu/sites/default/files/legacy/kiadvany/Kiadvany080707.pdf. 